\title{
CZY APLIKACJA GENIAL.LY RZECZYWIŚCIE JEST GENIALNA? O POTENCJALE NARZĘDZI ONLINE PODCZAS ZDALNEGO NAUCZANIA JEZZYKA POLSKIEGO JAKO OBCEGO
}

Słowa kluczowe: język polski jako obcy, aplikacja, zdalne nauczanie, Genial.ly, lekcje online

Streszczenie. Celem artykułu jest przedstawienie możliwości wykorzystania narzędzia Genial.ly podczas zdalnych zajęć z cudzoziemcami. Aplikacja umożliwia nie tylko tworzenie gier, quizów lub pokoi zagadek, ale także infografik, interaktywnych ilustracji, przewodników, zadań typu prawda-fałsz, ćwiczeń polegających na łączeniu par oraz uzupełnianiu osi czasu lub mapy. Nauczyciel ma również możliwość zaprojektowania prezentacji w trzech wariantach: tradycyjnym - z użyciem tekstu oraz grafiki, wideo - w formie krótkiego filmu, który może stanowić alternatywę dla webinarów, a także w wersji rozdziału z podręcznika łączącego treści wprowadzane podczas zajęć z krótkim quizem sprawdzającym przyswojoną wiedzę. Artykuł nie tylko prezentuje potencjał popularnej aplikacji, ale podaje również przykłady konkretnych sposobów wykorzystania narzędzia podczas lekcji języka polskiego jako obcego. Przedstawione zadania stworzone w aplikacji Genial.ly zostały zweryfikowane w grupach cudzoziemskich podczas zajęć prowadzonych zdalnie, zarówno jako element lekcji w czasie rzeczywistym, jak i praca domowa.

\section{1. ŚWIAT UCZY SIE ZDALNIE}

Rok 2020 okazał się wyjątkowy pod względem zmian, które pojawiły się nie tylko w życiu Polaków czy Europejczyków, ale także w mniejszym lub większym stopniu wśród mieszkańców wszystkich krajów na świecie. Epidemia koronawirusa zobligowała władze wielu państw do podjęcia istotnych działań, które

*paulina.kazmierczak@edu.uni.lodz.pl, Uniwersytet Łódzki, Wydział Filologiczny, Zakład Lingwistyki Stosowanej i Kulturowej, Instytut Filologii Polskiej i Logopedii, ul. Pomorska 171/173, 90-236 Łódź. 
mogłyby zmniejszyć ryzyko zakażenia. Jedna z tego typu decyzji ${ }^{1}$ dotyczyła zamknięcia szkół i uczelni wyższych.

W poszczególnych krajach wdrożono nowe sposoby edukowania dzieci i młodzieży. Najczęściej przekaz miał formę radiową, telewizyjną lub internetową. W tym ostatnim przypadku były to zarówno platformy umożliwiające oglądanie filmów edukacyjnych, np. TED-Ed (online 2) lub YouTube (online 3), a także strony ministerialne z pomocami dydaktycznymi lub aplikacje umożliwiające korzystanie z e-booków (online 4).

Proponowane rozwiązania dotyczą przede wszystkim edukacji szkolnej lub uniwersyteckiej. Warto jednak zauważyć, że zajęcia z języka polskiego jako obcego charakteryzują się odmienną specyfiką. Ponadto często odbywają się w prywatnych szkołach językowych lub w czasie obowiązkowych lektoratów na studiach, co uniemożliwia stosowanie rozwiązań systemowych i wymaga większej indywidualizacji działań niż proponowana przez rząd. Zazwyczaj lekcje prowadzone są w grupach zróżnicowanych kulturowo, a uczniowie mają odmienne doświadczenia w kwestii nauki innych języków. Oprócz typowych trudności związanych z indywidualnymi predyspozycjami lingwistycznymi lub cechami charakteru, które warunkują pracę własną studentów, pojawiła się nowa bariera poznawcza - edukacja zdalna.

Niewątpliwie konieczność zmiany dotychczasowego stylu prowadzenia zajęć to ważne wydarzenie zarówno dla uczniów, jak i nauczycieli. Z jednej strony przeniesienie lekcji do wirtualnej rzeczywistości może stanowić istotny problem pod względem technologicznym oraz kompetencyjnym. Z drugiej jest szansą na rozwój w dziedzinie, która dotąd była pomijana. Oczywiście, możliwość korzystania z komputera i rzutnika podczas tradycyjnych zajęć, wymagała wprowadzania nowych technologii do procesu kształcenia. Pojawiały się prezentacje multimedialne, filmy, a nawet gry oraz aplikacje. Jednak najczęściej stanowiły one jedynie element lekcji. Sytuacja uległa zmianie w chwili rozpoczęcia kształcenia zdalnego.

\section{GENIALNA APLIKACJA - POTENCJAŁ APLIKACJI GENIAL.LY}

Celem niniejszego artykułu jest przedstawienie kilku sposobów przezwyciężania trudności związanych ze zdalnym prowadzeniem zajęć z języka polskiego jako obcego oraz zaprezentowanie możliwości doskonalenia kompetencji cyfrowych studentów i lektorów na przykładzie aplikacji Genial.ly.

${ }^{1}$ Zasięg zjawiska można obserwować na mapie przygotowanej według statystyk prowadzonych przez UNESCO (online 1). 
Powstała ona w Hiszpanii w 2015 roku. Jej wszechstronne zastosowanie potwierdza liczne, bo ponad trzymilionowe grono użytkowników w ponad stu krajach. Narzędzie umożliwia stworzenie około 25 rodzajów projektów biznesowych, medialnych lub dydaktycznych (online 5). To właśnie sukces w ostatniej z wymienionych dziedzin sprawił, że podczas londyńskich targów technologiczno-edukacyjnych BETT Show otrzymało ono nagrodę Global Edtech Startup Awards (GESA) (online 6). Genial.ly powstało jako start-up, czyli 'przedsięwzięcie, które stworzono w celu wykreowania nowego produktu bądź usługi w warunkach ryzykownych, braku pewności' (online 7). Założeniem twórców było udoskonalenie komunikacji internetowej tak, aby oprócz treści uwzględniała również przekaz graficzny. Aplikacja umożliwia tworzenie różnorodnych form wirtualnego informowania. Interfejs dostępny jest w trzech językach: hiszpańskim, francuskim $\mathrm{i}$ angielskim. Jednak nie stanowi to problemu, ponieważ nawet osoba z podstawową znajomością języka będzie w stanie wykreować własną grafikę dzięki intuicyjności narzędzia.

Pierwszym etapem pracy z Genial.ly jest założenie konta. Warto podkreślić, że logowanie wymaga jedynie podania adresu e-mail oraz wymyślenia hasła. Możliwa jest również rejestracja przez Google, Facebook, LinkedIn, Twitter lub Office365 (online 8). Następnie należy określić rodzaj pakietu, w ramach którego będzie się korzystać z aplikacji. Podstawowy podział dotyczy wersji edukacyjnej, przeznaczonej dla uczniów, nauczycieli i szkół, z podtypami: darmowy, studencki, edukacyjny profesjonalny, mistrzowski oraz wersji bardziej zaawansowanej, powszechnej w sferze medialnej lub biznesowej, w wariantach: darmowy, profesjonalny, mistrzowski, grupowy. Każdy pakiet można opłacić w formie rocznego, a warianty zaznaczone wyżej pogrubionym pismem również miesięcznego abonamentu. Najważniejsza różnica między wersją darmową a pozostałymi to brak możliwości korzystania z utworzonych grafik w trybie offline oraz ograniczony dostęp do szablonów (online 9). Warto jednak podkreślić, że liczba bezpłatnych wzorów jest wystarczająca dla początkującego użytkownika. Praca z aplikacją nie wymaga umiejętności programowania lub zaawansowanej obsługi komputera, ale należy wziąć pod uwagę, że jest czasochłonna, zwłaszcza podczas pierwszych prób. Poniżej zestawiono wszystkie możliwości wykorzystania narzędzia.

Tabela 1. Genial.ly - możliwości wykorzystania

\begin{tabular}{|c|l|}
\hline NAZWA & OPIS I FUNKCJE \\
\hline Presentation & $\begin{array}{l}\text { Umożliwia wykorzystanie nietypowych szablonów - w zależności od wybra- } \\
\text { nego pakietu może to być motyw, np.: strony z gazety, tekstu pisanego piórem } \\
\text { na pergaminie, gry wideo lub czarno-białego filmu. To sposób, aby uatrakcyj- } \\
\text { nić ćwiczenie sprawności językowych, np. podczas pracy ze spreparowanym } \\
\text { lub autentycznym tekstem. Dodatkowym atutem są animacje, a także interak- } \\
\text { tywne elementy odsyłające do treści dostępnych online - filmów, stron www. }\end{array}$ \\
\hline
\end{tabular}


Tabela 1. (cd.)

\begin{tabular}{|c|c|}
\hline NAZWA & OPIS I FUNKCJE \\
\hline Dossier\&Report & $\begin{array}{l}\text { Szablony mogą mieć formę czasopisma lub interaktywnej prezentacji z mo- } \\
\text { tywem miejskim bądź przyrodniczym. Istotnym elementem są diagramy, wy- } \\
\text { kresy i osie czasu przydatne m.in. podczas analizy tekstów specjalistycznych } \\
\text { zawierających dane statystyczne. Ponadto szablony dokumentów, planów bu- } \\
\text { dżetowych lub ofert sprzedaży mogą być przydatne w czasie lekcji polskiego } \\
\text { języka biznesowego. }\end{array}$ \\
\hline $\begin{array}{l}\text { Learning } \\
\text { Experience }\end{array}$ & $\begin{array}{l}\text { Szablony umożliwiają przeprowadzenie quizu lub zadania polegającego na } \\
\text { łączeniu w pary, dopasowywaniu bądź uzupełnianiu. Wśród dostępnych moty- } \\
\text { wów można znaleźć: baśń, mapę świata, kosmos, a nawet odniesienie do eks- } \\
\text { perymentu Schrödingera, którego rezultat jest weryfikowany przez poprawną } \\
\text { odpowiedź gracza. } \\
\text { Ponadto można wykorzystać imitację fragmentów podręcznika. Forma gra- } \\
\text { ficzna nawiązuje m.in. do matematyki, robotyki, historii lub ma postać kartek } \\
\text { wyrywanych kolejno z notatnika. Istotnymi elementami są: spis treści po- } \\
\text { rządkujący wprowadzane zagadnienia oraz quiz lub gra sprawdzająca stopień } \\
\text { przyswojenia wiedzy. } \\
\text { Narzędzie jest przydatne do stworzenia gotowej lekcji z elementem sprawdza- } \\
\text { jącym jej opanowanie. }\end{array}$ \\
\hline Gamification & $\begin{array}{l}\text { Szablony występują w trzech wariantach. Pierwszy z nich ma formę zdjęcia, } \\
\text { które można obrócić lub zmienić jednym kliknięciem, co umożliwia m.in. } \\
\text { stworzenie fiszek do nauki nowych słówek. Drugi pozwala na opracowanie: } \\
\text { - } \quad \text { quizów, np. z motywem superbohaterów, zawodów pływackich lub roz- } \\
\text { brajania bomby; } \\
\text { - } \quad \text { gry wideo - PacMan lub Invaders; } \\
\text { - } \quad \text { gry planszowej, np. w postaci adaptacji Monopoly albo Jumanji; } \\
\text { - } \quad \text { gry towarzyskiej - koło fortuny, kręgle, mafia bądź memory; } \\
\text { - labiryntu sekwencji, który polega na wybraniu właściwej trasy i otwo- } \\
\text { rzeniu kłódki za pomocą hasła stworzonego z liter zdobywanych podczas } \\
\text { rozgrywki. } \\
\text { Wszystkie wymienione gry można dostosować do bieżącej tematyki zajęć ję- } \\
\text { zykowych, podobnie jak trzeci wariant, który umożliwia stworzenie wirtualne- } \\
\text { go pokoju zagadek. Jest to seria zadań (zagadek), których rozwiązanie skutkuje } \\
\text { zdobyciem klucza, odkryciem tajemnicy lub odnalezieniem drogi w zależności } \\
\text { od przyjętej fabuły, np.: kosmos, fabryka, gra wideo lub wehikuł czasu. }\end{array}$ \\
\hline $\begin{array}{l}\text { Interactive } \\
\text { Image }\end{array}$ & $\begin{array}{l}\text { Lektor może wykorzystać obrazek lub zdjęcie, na którym umieści punkty od- } \\
\text { syłające do filmów, stron www, informacji, zadań, gier związanych tematycz- } \\
\text { nie z prezentowanym zagadnieniem. }\end{array}$ \\
\hline
\end{tabular}




\begin{tabular}{|c|c|}
\hline $\begin{array}{l}\text { Horizontal } \\
\text { Infographic }\end{array}$ & $\begin{array}{l}\text { Pozioma infografika umożliwia prezentację treści na pojedynczym slajdzie } \\
\text { w formie: } \\
\text { - } \quad \text { przeglądu - np.: mapa myśli, matryca kompetencyjna, analiza SWOT, ta- } \\
\text { bela zadań, drzewo problemowe, strona z książki lub kadr z filmu, plakat; } \\
\text { - } \quad \text { osi czasu - motyw ewolucji, kadru filmowego, historii, podróży, roz- } \\
\text { grywki footballu amerykańskiego; } \\
\text { - } \quad \text { diagramu; } \\
\text { - } \quad \text { listy - np.: paleta z farbami, zdjęcie klasowe, linijka, drużyna piłkarska, } \\
\text { pająk, szafa grająca, pięciolinia; } \\
\text { mapy - uwzględniono świat, kontynenty, oceany oraz Hiszpanię*. Pod } \\
\text { względem formy są dostępne wersje: rysunkowa, radarowa, pergamino- } \\
\text { wa, a także puzzle 2D i 3D. }\end{array}$ \\
\hline $\begin{array}{l}\text { Vertical } \\
\text { Infographic }\end{array}$ & $\begin{array}{l}\text { Pionowa infografika, ze względu na dostępne motywy, może być wykorzy- } \\
\text { stywana podczas realizacji tematów związanych z podróżami, przyrodą, go- } \\
\text { towaniem. Dodatkową zaletą jest możliwość umieszczenia na niej osi czasu } \\
\text { lub listy. }\end{array}$ \\
\hline Guide & $\begin{array}{l}\text { Umożliwia przedstawienie treści, w postaci zestawienia tekstu oraz ilustracji, } \\
\text { w odpowiedniej kolejności. Grafika jest dobrana w taki sposób, by wymuszała } \\
\text { zaplanowanie układu prezentowanych informacji. }\end{array}$ \\
\hline $\begin{array}{c}\text { Video } \\
\text { Presentation }\end{array}$ & $\begin{array}{l}\text { Łączy treść tekstową } \mathrm{z} \text { graficzną } \mathrm{i} \text { pozwala przedstawić je w formie } \\
\text { nietuzinkowych animacji. Popularne motywy to: przyroda, kosmos, notatka } \\
\text { lub graffiti. }\end{array}$ \\
\hline $\begin{array}{l}\text { Personal } \\
\text { Branding }\end{array}$ & $\begin{array}{l}\text { Umożliwia projektowanie interaktywnego CV lub portfolio, co jest przydatne } \\
\text { podczas realizacji tematu dotyczącego pracy. }\end{array}$ \\
\hline Social & $\begin{array}{l}\text { Narzędzie służące do tworzenia grafiki wykorzystywanej w mediach społecz- } \\
\text { nościowych. Przykłady to: } \\
\text { - } \quad \text { zdjęcie zmieniane jednym kliknięciem - popularne motywy to m.in.: } \\
\text { - } \quad \text { posran kinowy, projektor, szkolna tablica, teleskop lub mikroskop; } \\
\quad \text { z życzeniami; } \\
\text { - } \quad \text { posty kwadratowe - motyw karnawałowy bądź urodzinowy; } \\
\text { - } \quad \text { posty pionowe - odniesienia do listu gończego lub okładki magazynu, } \\
\text { książki, albumu; } \\
\text { - nagłówki - motyw związany z naturą bądź technologią. } \\
\text { Szablony można wykorzystać podczas wprowadzania krótkich form pisem- } \\
\text { nych, np. życzeń, zaproszeń. }\end{array}$ \\
\hline Blank Creation & $\begin{array}{l}\text { Pozwala tworzyć od podstaw, czyli zgodnie z indywidualnymi potrzebami } \\
\text { i bez szablonów, zarówno infografiki, jak i nagłówki oraz posty. }\end{array}$ \\
\hline
\end{tabular}

* To kraj twórców aplikacji.

Źródło: opracowanie własne 
Genial.ly cieszy się ogromnym zainteresowaniem Polaków, szczególnie nauczycieli przedmiotowych. Dowodem są artykuły w kwartalnikach „Biblioteka” (Halicka 2019) oraz „TIK w edukacji” (Osowska 2017) i wpisy na blogach (online 10). Nie brakuje także szkoleń doskonalących umiejętność korzystania z aplikacji (online 11), a także konkretnych instrukcji, ułatwiających przygotowanie poszczególnych elementów graficznych, np. interaktywnych ilustracji (online 12 online 13) lub dokumentacji i raportów zaadaptowanych na potrzeby lekcji (online 14). Rozwiązania trudności dotyczących obsługi aplikacji lub kłopotów związanych z brakiem pomysłów na wykorzystanie potencjału narzędzia można znaleźć na portalu społecznościowym Facebook w grupie Discovering genially - Polska, którą prowadzą krajowe ambasadorki firmy (online 15).

Nowoczesne technologie zyskują uznanie również wśród nauczycieli języka polskiego jako obcego (Gruza, Pabiańczyk 2016), szczególnie w sytuacji zmiany sposobu kształcenia (online 16). Jednak podobnie jak w przypadku każdego innego przedmiotu, korzystanie z aplikacji wymaga zaadaptowania dostępnych szablonów na potrzeby zajęć.

\section{LEKCJE Z GENIAL.LY}

Pomoce dydaktyczne ${ }^{2}$ zaprezentowane $\mathrm{w}$ artykule stosowano $\mathrm{w}$ trzech grupach, z których każda w momencie przeprowadzania zajęć nie liczyła więcej niż 10 osób. Pierwsza rozpoczęła kurs trzy miesiące wcześniej, kolejna była w trakcie drugiego semestru nauki, a ostatnia kończyła czwarty semestr lekcji języka polskiego. Wszyscy uczestnicy to studenci jednej z łódzkich uczelni. Kurs, w którym brali udział, odbywał się w wymiarze półtorej godziny tygodniowo i ze względu na sytuację epidemiologiczną został przeprowadzony zdalnie.

Lekcje odbywały się przy użyciu platformy ClickMeeting, dzięki której uczniowie mieli namiastkę rzeczywistego spotkania, ponieważ możliwe było zarówno połączenie audio, jak i wideo. Podstawowym problemem podczas zajęć okazały się kwestie techniczne. Część studentów korzystała z komputera, inni z telefonów lub tabletów. Odnoszenie się do materiałów w wersji papierowej - podręcznika lub zadań przesłanych wcześniej do wydrukowania - byłoby czasochłonne w perspektywie krótkiej lekcji raz w tygodniu, a dla osób bez dostępu do drukarki wręcz niemożliwe. $Z$ kolei wspólne rozwiązywanie zadań w pliku online często skutkowało rozproszeniem uwagi osoby, która nie jest w danym momencie proszona o odpowiedź. Niezbędne było opracowanie materiałów, które ułatwiłyby skupienie, a także umożliwiły jednocześnie powtórzenie materiału,

${ }^{2}$ Wszystkie materiały mają status publiczny, więc można z nich korzystać z poszanowaniem praw autorskich. 
pracę indywidualną i grupową. Istotną pomocą okazała się aplikacja Genial.ly, która dzięki elementom graficznym skutecznie rozbudzała skojarzenia u wzrokowców. Natomiast możliwość rzeczywistego działania oraz słuchania wypowiedzi lub piosenek w języku polskim ułatwiała pracę kinestetykom i słuchowcom.

\subsection{RODZINA - WPROWADZANIE LEKSYKI}

Pierwsza lekcja przeprowadzona z narzędziem online ${ }^{3}$ dotyczyła wprowadzania leksyki określającej rodzinę i odbyła się w grupie początkującej. Wykorzystano poziomą infografikę w formie listy, której motywem przewodnim był mecz piłki nożnej (genial.ly 1$)^{4}$. Studenci korzystali z aplikacji za pośrednictwem ekranu udostępnionego przez lektora. Grafika składała się z dwóch slajdów - w zależności od drużyny. Na każdym z nich było 11 zawodników, a oprócz informacji, kim jest dana osoba, można było zobaczyć ilustrujący ją obrazek. Rozgrywka odbywała się między zespołem kobiet i mężczyzn. Pierwszy skład to m.in. babcia stojąca na bramce, mama i ciocia w roli obrońców, córka - pomocnik oraz wnuczka jako napastnik. Przeciwnicy mieli dokładnie taki sam układ graczy, ale określenia występowały w męskich odpowiednikach. Po wprowadzeniu leksyki i skontrolowaniu poprawności wymowy można było przejść do pytań utrwalających przedstawioną na poprzednich zajęciach różnicę między mianownikiem i narzędnikiem. Oprócz słownictwa nazywającego członków rodziny, studenci mieli okazję poznać również nazwy pozycji piłkarskich.

Kolejna lekcja, zawierająca opisaną wcześniej leksykę, odbyła się gdy uczniowie nie tylko potrafili odpowiedzieć na pytania o imię, wiek lub miejsce zamieszkania, lecz także umieli opisać wygląd i charakter postaci. Tym razem wykorzystano prezentację, której motywem przewodnim był album fotograficzny zatytułowany Kowalscy i Nowakowie (genial.ly 2). Znajdowały się w nim opisy poszczególnych członków rodziny, obok których brakowało właściwych ilustracji. Zdjęcia znajdowały się w drugiej części albumu. Na podstawie opisów uczniowie musieli dopasować numer zdjęcia do określonej postaci i stworzyć drzewo genealogiczne obu rodzin. Album zakończono rozwiązaniem zadania, co umożliwiło weryfikację roboczej wersji koligacji rodzinnych opisywanej wspólnie w pliku tekstowym. Ponadto na ostatniej karcie studenci ujrzeli mapę świata. Najpierw ich zadaniem była odpowiedź na pytanie, kto z Kowalskich lub Nowaków mieszka w zaznaczonych krajach, a następnie - gdzie mieszkają wybrani

\footnotetext{
${ }^{3}$ Podczas lektury niniejszego artykułu wskazane jest otwieranie linków, odsyłających do poszczególnych zadań, które umieszczono w bibliografii.

${ }^{4}$ Wszystkie szablony, które zostały opisane w artykule, wybrano na podstawie subiektywnej oceny możliwości dostosowania ich do tematyki zajęć.
} 
członkowie rodów. Zaprezentowana forma pracy była okazją do praktycznej weryfikacji sprawności czytania, a także do sprawdzenia umiejętności globalnego rozumienia tekstów oraz utrwalenia wprowadzonych wcześniej treści.

\subsection{CZASY - UTRWALENIE ZAGADNIEŃ GRAMATYCZNYCH}

Zadania uwzględniające zagadnienia gramatyczne przeprowadzono $\mathrm{w}$ formie powtórzeń. Pierwsze z nich wykonano w grupie studentów będących po półrocznym kursie. Dotyczyło zestawienia wszystkich typów koniugacji czasu teraźniejszego - po ich uprzednim wprowadzeniu i przećwiczeniu. Kolejne stanowiło podsumowanie informacji na temat poznanych dotąd ${ }^{5}$ czasów w języku polskim. Uczestniczyli w nim cudzoziemcy w trakcie drugiego roku nauki.

Przygotowanie zadania umożliwiającego powtórzenie koniugacji wymagało zastosowania pionowej infografiki (genial.ly 3). Górna część uwzględniała leksykę obligującą do użycia czasu teraźniejszego. Następna zawierała nazwy koniugacji, które po kliknięciu ukazywały informacje na temat zasad tworzenia poszczególnych typów odmiany. Kolejny element grafiki to interaktywne zadanie złożone z trzech części poprzedzonych przykładem. Polegało ono na wysłuchaniu reklamy i zaznaczeniu czasowników w czasie teraźniejszym. W wersji testowej, ilustrującej sposób wykonania zadania, wykorzystano film promocyjny popularnej gumy do żucia emitowany w latach dziewięćdziesiątych. Pod nagraniem umieszczono transkrypcję tekstu i zaznaczono w niej wyrazy nazywające czynności. Studenci analogicznie mieli wykonać całe ćwiczenie. Podczas zajęć w grupie było sześć osób, więc uczniowie pracowali w parach - w zależności od platformy lub komunikatora mogą działać pojedynczo, aby potem na forum porównać rezultaty bądź od początku konsultować się przy wyborze czasowników. Warto podkreślić, że w wykorzystanych reklamach oprócz czasu teraźniejszego pojawił się również czas przyszły prosty oraz tryb rozkazujący. Ćwiczenie stanowi zatem okazję, by uświadomić studentom, że nie każdy leksem, który określa czynność lub ma końcówkę typową dla danej koniugacji musi być tożsamy z poszukiwaną formą. Ostatnia część zawierała trzy zadania: quiz (genial.ly 4), piosenkę oraz grę (genial.ly 5). Pierwszy z wymienionych elementów wymagał wybrania poprawnego czasownika lub koniugacji. Drugi polegał na uzupełnieniu tekstu popularnego utworu i dopisaniu bezokoliczników do usłyszanych wyrazów. Niestety, infografika nie umożliwia nanoszenia zmian bezpośrednio w zadaniu, więc studenci musieli robić notatki w osobnym pliku tekstowym lub na kartce. Trzecie ćwiczenie to adaptacja gry memory. Podczas zajęć uczniowie najpierw mówili po polsku, z jakimi czynnościami kojarzą się im poszczególne obrazki, a następnie

\footnotetext{
${ }^{5}$ Ćwiczenie nie uwzględnia czasu przyszłego prostego.
} 
starali się zapamiętać ich kolejność i wskazać ten, o który byli pytani w danej rundzie.

Zadanie utrwalające zasady tworzenia form czasowników przeszłych, teraźniejszych i przyszłych wykorzystano w bardziej zaawansowanej grupie jako pracę domową. Do interaktywnej ilustracji (genial.ly 6), przedstawiającej biegnące kobiety, dodano trzy cyfry. Po kliknięciu na każdą z nich pojawiała się skrócona informacja na temat sposobu tworzenia danego czasu. Kolejność numeracji odzwierciedlała tę, według której wprowadzano zagadnienie na zajęciach. Oprócz cyfr na ilustracji znajdowały się również odnośniki do zadań w ramach pracy domowej ${ }^{6}$. Po kliknięciu na dane oznaczenie uczeń mógł posłuchać piosenki i uzupełnić brakujące formy czasowników. Ćwiczenie wykorzystano w ramach pracy indywidualnej, więc oprócz umieszczenia na ilustracji krótkiej legendy wyjaśniającej poszczególne symbole literowe lub cyfrowe, niezbędne było również uwzględnienie polecenia.

\subsection{SŁAWNI POLACY - WPROWADZENIE ELEMENTÓW KULTUROWYCH}

Ostatniezadanieprzygotowaneprzy pomocyaplikacjiGenial.lyprzeprowadzono w dwóch grupach - najbardziej i najmniej zawansowanej. Ćwiczenie miało formę pokoju zagadek, którego motywem przewodnim byli znani Polacy (genial.ly 7). Rozgrywka składała się z sześciu zadań lub zagadek: Wprowadzenie, Quiz, Gdzie to jest?, Kto to jest?, Kogo tutaj nie ma? oraz Prezent. Studenci musieli rozwiązać poszczególne ćwiczenia, aby zdobyć cyfry tworzące kod. Odkrycie poprawnej kombinacji umożliwiało studentom znalezienie odpowiedzi na pytanie stanowiące kanwę gry - Jaki prezent dostają sławni Polacy?

Pierwszy element odesłał uczniów do prezentacji wideo (genial.ly 8), która przedstawiałalaureatów Nagrody Nobla, sportowców, muzykówipiosenkarzyzwiązanych z Polską. Najpierw studenci obejrzeli krótki film dotyczący noblistek i noblistów, który zamieszczono na platformie YouTube, na kanale Eduelo (genial.ly 9). Następnie ich zadaniem było wskazanie, jakie nazwisko odpowiadało wizerunkowi laureatki bądź laureata. Kolejna część prezentacji dotyczyła znanych sportowców. Studenci mieli kilka minut, aby poszukać informacji na ich temat w internecie. Potem wspólnie dopasowywali osobę do zdjęcia oraz rozwiązywali quiz (genial.ly 10) dotyczący dyscyplin, jakie uprawiają wymienieni Polacy. Druga połowa prezentacji obejmowała muzyków oraz piosenkarzy i wymagała połączenia ilustracji z nazwiskiem. Do zdjęć dołączono elementy interaktywne, które odsyłały do utworów omawianych twórców, więc można było wspólnie odsłuchać fragmenty lub potraktować tę część jako pracę własną uczniów.

\footnotetext{
${ }^{6}$ Zadania oznaczono literą P.
} 
Po powrocie do strony głównej pokoju zagadek studenci musieli wybrać, od którego zadania chcieliby zacząć. Obie grupy zdecydowały się na zachowanie kolejności ze względu na fakt, że zdobyte w rozgrywkach cyfry miały tworzyć kod niezbędny do rozwiązania zagadki. Na początku cudzoziemcy zmierzyli się z quizem dotyczącym noblistów. Następnie wykonali ćwiczenie wymagające znalezienia na czarnym tle, za pomocą latarki, imion i nazwisk znanych Polaków. Studenci musieli odkryć, która z osób nie pasuje do grupy. Warto podkreślić, że uczniowie odpowiadali wspólnie, a lektor zaznaczał wybrane przez nich odpowiedzi, więc ostateczna decyzja musiała zostać właściwie umotywowana przez graczy. Dzięki temu uczniowie mogli utrwalić leksykę dotyczącą zawodów oraz formy mianownika i narzędnika. Następny etap, czyli Kto to jest?, polegał na rozpoznaniu zdjęć sławnych Polaków. Po otrzymaniu trzeciej części kodu można było przejść do ostatniego zadania - Kogo tutaj nie ma?. Składało się ono $\mathrm{z}$ dwóch poziomych rzędów. W górnym brakowało jednego elementu, a dokładnie nazwiska, które należało wybrać z dolnej części wyjaśniając powód podjętej decyzji. Po rozwiązaniu wszystkich zagadek studenci przeszli do części zatytułowanej Prezent i odkryli odpowiedź na pytanie zadane na początku rozgrywki.

\section{CZY GENIAL.LY JEST GENIALNE?}

Odpowiedź na pytanie zawarte w tytule artykułu nie jest jednoznaczna, zależy bowiem od kreatywności użytkownika aplikacji. Genial.ly to doskonałe narzędzie dla osób, które w trakcie zajęć chcą korzystać z multimediów, interaktywnych odniesień oraz nietuzinkowych rozwiązań graficznych. Dla lektora języka polskiego jako obcego to nie tylko szansa na rozwój kompetencji cyfrowych, ale również urozmaicenie lekcji. Aplikacja może być wykorzystywana na wszystkich zajęciach, niezależnie od poruszanego tematu. Właściwa adaptacja sprawi, że umożliwi ona wprowadzenie leksyki, utrwalenie gramatyki, a także rozwinięcie kompetencji kulturowej uczniów.

Oczywiście, jak każde narzędzie związane z nową technologią, ma również wady. W przypadku korzystania $\mathrm{z}$ darmowej wersji dotyczą one głównie niemożności pracy z utworzonymi materiałami bez dostępu do internetu oraz konieczności upublicznienia wszystkich projektów. Ponadto pierwsze próby wykorzystania aplikacji mogą wymagać wytrwałości i praktyki, a niejednokrotnie także weryfikacji podczas zajęć. Wiele błędów można zauważyć dopiero w czasie testowania gry lub grafiki z cudzoziemcami.

Mimo nielicznych trudności, jakie mogą pojawić się na początku użytkowania Genial.ly, warto skupić się na pozytywnych aspektach narzędzia. Jest ono niezwykle intuicyjne, a każdy projekt wyposażono w opcję pokazywania interak- 
tywnych elementów. Stanowi to duże ułatwienie dla uczniów i nauczycieli, którzy nie są cyfrowymi tubylcami.

Liczne propozycje szablonów, z których można korzystać, przygotowując zajęcia, powodują, że nawet żmudne ćwiczenia gramatyczne prezentowane są w zupełnie nowej odsłonie. Dzięki interaktywności ilustracji student ma szansę zapoznać się z rzeczywistym użyciem języka w tekstach, filmach czy muzyce. Połączenie kompetencji językowej i komunikacyjnej zwiększa jego szanse na opanowanie polszczyzny oraz równomierny rozwój poszczególnych sprawności (Lipińska, Seretny 2005). Nie sposób pominąć fakt, że praca z wykorzystaniem aplikacji sprzyja rozwojowi mózgu. Dostarcza bodźców wzrokowych i słuchowych oraz umożliwia grupową lub indywidualną aktywność studentów. Ponadto intryguje, co z pewnością wynika z innowacyjności narzędzia Genial.ly, a tym samym sprzyja funkcjonowaniu mózgu (Żylińska 2013, s. 83-92). Niejednokrotnie korzystanie z tego narzędzia zaspokaja również potrzeby estetyczne uczniów i nauczycieli.

Genial.ly umożliwia prowadzenie zajęć z wykorzystaniem elementów gamifikacji, która od dłuższego czasu zyskuje coraz większą popularność, a obecna sytuacja poszerzyła grono jej zwolenników (online 17). Aplikacja daje także namiastkę edukacji przez doświadczenie, dzięki czemu może się sprawdzić nie tylko w środowisku dzieci lub młodzieży, ale również osób dorosłych (Szczepan-Jakubowska 2017, s. 54-55).

\section{BIBLIOGRAFIA}

genial.ly 1: https://view.genial.ly/5ecd7ec18035300d8e160bf9/horizontal-infographic-lists-rodzina -kobiety-vs-mezczyzni [06.06.2020].

genial.ly 2: https://view.genial.ly/5ed50e835267300d859bab8f/presentation-album-rodzinny [06.06.2020].

genial.ly 3: https://view.genial.ly/5ed7b9f5fa75bb0d9d179ae5/vertical-infographic-czas-terazniejszy [06.06.2020].

genial.ly 4: https://view.genial.ly/5ed7cf23fa75bb0d9d179dbc/game-rzutki-czas-terazniejszy [06.06.2020].

genial.ly 5: https:/view.genial.ly/5ed7d30723f1c90d96099e2a/game-memory-czasowniki [06.06.2020].

genial.ly 6: https://view.genial.ly/5ece86f94cb8330da0633ef9/interactive-image-czasy [06.06.2020].

genial.ly 7: https://view.genial.ly/5ed8e945c1e3480d9b9c9abd/game-breakout-znani-polacy-pokoj -zagadek [06.06.2020].

genial.ly 8: https://view.genial.ly/5ede4c0ad02b340d647a9b2b/video-presentation-znani-polacy [06.06.2020].

genial.ly 9: https://www.eduelo.pl [06.06.2020].

genial.ly 10: https://view.genial.ly/5edf4b00fa7f690d0c882f04/learning-experience-challenges -sportowcy [06.06.2020]. 
Gruza D., Pabiańczyk A., 2016, Język polski 2.0 - zastosowanie nowoczesnych technologii w nauczaniu języka polskiego, Warszawa.

Halicka A., 2019, Genial.ly - genialna platforma dla nowoczesnych nauczycieli, „Biblioteka - Centrum Informacji”, nr 2, s. 8-13.

Lipińska E., Seretny A., 2005, ABC metodyki nauczania języka polskiego jako obcego, Kraków.

online 1: https://en.unesco.org/covid19/educationresponse [06.06.2020].

online 2: https://ed.ted.com [06.06.2020].

online 3: https://www.youtube.com [06.06.2020].

online 4: https://en.unesco.org/covid19/educationresponse/nationalresponses [06.06.2020].

online 5: https://mamstartup.pl/genial-ly-zebralo-runde-w-wysokosci-5-milionow-dolarow

[6.05.2020].

online 6: https://blog.genial.ly/en/bett-2020-reward-experience/ [06.06.2020].

online 7: https://startupacademy.pl/co-to-jest-startup/ [06.06.2020].

online 8: https://www.genial.ly/login [06.06.2020].

online 9: https://app.genial.ly/plans?from=burgerbar_my_plan [06.06.2020].

online 10: http://www.superbelfrzy.edu.pl/glowna/genially-genialne-narzedzie-na-czas-edukcji-zdalnej-i-nie-tylko/ [06.06.2020].

online 11: https://etwinning.pl/tydzien-z-genial-ly/ [06.06.2020].

online 12: https://www.specjalni.pl/2020/03/plakat-w-genialy-wiosenne-zadania.html [06.06.2020].

online 13: https://polonistkaprzytablicy.blogspot.com/2020/02/instrukcja-genially.html?m=0 [06.06.2020].

online 14: https://www.polskizklasa.pl/genialne-genially-czyli-instrukcja-dla-poczatkujacych/ [06.06.2020].

online 15: https://www.facebook.com/groups/868064883659074/ [06.06.2020].

online 16: http://www.polskamacierz.com/gdzieszukacinspiracji.html [06.06.2020].

online 17: http://eduplus.com.pl [06.06.2020].

Osowska I., 2017, Genial.ly - genialna pomoc dydaktyczna, „TIK w edukacji”, nr 6, s. 54-55.

Szczepan-Jakubowska D., 2017, Nauka przez doświadczenie i działanie-przyszłość organizacji i przyszłość szkoleń, w: M. Gromadzka (red.), Uczenie dorostych okiem praktyka, Warszawa.

Żylińska M., 2013, Neurodydaktyka. Nauczanie i uczenie się przyjazne mózgowi, Toruń, s. 83-92.

\section{Paulina Kaźmierczak}

\section{IS THE GENIAL.LY APP REALLY PHENOMENAL? ABOUT POTENTIAL OF ONLINE TOOL DURING LESSONS OF POLISH AS A FOREIGN LANGUAGE} lessons

Keywords: Polish as a foreign language, application, long-distance learning, Genial.ly, online

\footnotetext{
Abstract. The aim of the article is to present the possibility of using the Genial.ly app during long-distance classes with foreigners. The application allows not only to create games, quizzes or escape rooms, but also infographics, interactive illustrations, guides, tasks true-false, exercises consisting in pairing and completing a timeline or map. This online tool give a possibility to design a presentation in three variants: traditional - using text and graphics, video - in the form of a short film, which can be an alternative to webinars, as well as textbook's chapter with introduction at the beginning and with a short quiz at the end. The article not only presents the potential of a popular application, but also gives examples how to use the tool during lessons of Polish as a foreign language. All tasks have been verified in groups of foreigners during classes as part of real-time lessons and as homework.
} 